\title{
STATISTICAL ANALYSIS OF THE INFLUENCE OF PRINT RUN ON SURFACE ROUGHNESS OF DIGITAL FLEXO PRINTING PLATES' SOLID TONE AREAS
}

\author{
Sandra Dedijer ${ }^{1}$ (D), Magdolna Pal ${ }^{1}$ (D), Ivana Tomić ${ }^{1}$ (D), Stefan Poljak ${ }^{2}$, \\ Živko Pavlović ${ }^{1}$ (D), Ivana Jurič ${ }^{1}$ (D), Neda Milić Keresteš ${ }^{1}$ (iD \\ ${ }^{1}$ University of Novi Sad, Faculty of Technical Sciences, \\ Department of Graphic Engineering and Design, Novi Sad, Serbia \\ ${ }^{2}$ Tetra Pak Produktions GmbH \& Co KG, Limburg, Germany
}

\begin{abstract}
In this study we have aimed to present statistical evaluation of changes in the surface roughness of the solid tone areas on CtP flexo printing plate in dependence of print run. Changes in flexo plate surface roughness is influenced by the plate-making process, printing pressure and speed, the interaction with the ink and printing substrate and by the wear of the printing plate due to long print-runs. Thus, the aim of this research was to evaluate the changes in the amplitude surface roughness parameters $(R a, R p$, $R v$ and $R z$ ), between the printing plates used for different print runs. In the experiment, we have employed three sets of CtP flexo printing plates, for three colors-cyan, magenta and blue. The first set was not used for printing, the second was used to print 7 rolls of substrate and the third is used to print 11 rolls of printing substrate. The amplitude surface roughness parameters were compared by applying independentsamples t-test method using the software SPSS (Statistical Package for Social Science) with a 0.05 significance level. Statistical analysis revealed that the difference between the amplitude surface roughness parameters measured on CtP flexo printing plates are significant with a 95\% confidence level, whereas the statistical significance pointed out that with the longer print runs, the difference will be strongly expressed.
\end{abstract}

Key words: CtP flexo printing plate, solid tone area, surface roughness, long print run

\section{INTRODUCTION}

Flexography is a direct printing technique primarily recognisable due to its exceptional ability to print on the various substrates delivering high quality imprints. Due to its cost effectiveness, versatility and efficiency, it became growing printing process on a highly demandable graphic arts industry market.

The printing substrates which can be utilized in flexography are mainly used in the packaging industry and are different types of the absorbent and non-absorbent materials, coated and uncoated paper board, metalized foils, paper foils and plastic films (Kipphan, 2001; Rentzhog, 2006; Lanska, 2007).

Flexography is a high-speed printing process which uses relief printing plates. It means that the image areas on the printing plate are raised above the non-image areas. Image areas receive the printing ink which is, due to slight contact pressure, transferred onto the printing substrate. The ink transfer concept in flexography is simple, but still there is a wide diapason of variable parameters which directly influence ink transfer and consequently the quality of the final printed result (Dedijer et al., 2012).

For example, printing pressures which are required to print solids and halftones differ significantly, which may result in image distortion especially if printing is conducted on substrates with textured surface (Bould et al, 2004). The flexographic printing plate is also one of the key factors which highly influence the stability and quality of the printing process.

In light of ink transferring, especially from the large solid areas which are not rare in flexography, the controlled and uniform ink transferring from the printing plate onto the printing substrate is a must if the high-quality output is a goal. One of the parameters which are directly linked with the ink transferring rate is printing plate surface property. The analyses of surface topography give relevant information to make possible prediction of behaviour of the flexo plate surface during printing process (Barros et al, 2005). Moderate surface roughness of flexo printing plate is desirable since it enables optimal ink transfer, while excessive roughness of the solid areas cause low solid ink density due to failure to make contact between the printing plate surface and a given substrate (Choi and O'Brate, 2010). Too low surface roughness may lead to again insufficient ink transfer onto the printing plate.

There are a variety of methods proposed in order to quantify the surface roughness: profilometric methods, like MSP-mechanical stylus contact profilometry or non-contact laser profilometry or different imaging methods such as SEM (Scanning Electron Microscopy) or AFM method (Atomic Force 
Microscopy) (Risović et al, 2009; Chappard et al, 2003). In direct contact profilometry, surface roughness is measured directly, where measuring unit's (sharp diamond tip) displacements are recorded and used for further surface roughness parameters calculation (Risović et al, 2009). Among many roughness parameters which can be used for the surface characterization, the most commonly used are amplitude ISO roughness parameters: Ra (average surface roughness), Rz (mean value of the single roughness depths $\mathrm{Zi}$ ), $\mathrm{Rp}$, the height from the highest profile peak and $\mathrm{Rv}$, the height from the lowest profile peak (Mahović, 2007; Pavlović et al, 2010).

In this paper we have explored the influence of print run on changes in surface roughness of solid tone areas on three sets of CtP flexo printing plates consisting of cyan, magenta (process colors) and blue (spot color) plate. The first set represents the CtP flexo printing plates that were not used in printing process, the second one consists of printing plates that were used for printing of 53075 meters of printing substrate, while the third set represents flexo plates used for printing the 82025 meters of the substrate. The obtained data were compared by applying independent-samples t-test in software SPSS (Statistical Package for Social Science, version 20) with a 0.05 significance level.

\section{METHODS}

The printing plates utilized in the experiment were digital flexo plates (Table 1). For the purpose of the experiment, printing plates were processed according to manufacturer's recommendation: UVA back exposure 35 seconds, UVA main exposure 10 minutes (lamp temperature $40^{\circ} \mathrm{C}$, intensity $19,6 \mathrm{~mW} / \mathrm{cm}^{2}$ ), developing speed $150 \mathrm{~mm} / \mathrm{min}$ (developer temperature $32^{\circ} \mathrm{C}$ ), drying 120 minutes (drying temperature $60^{\circ} \mathrm{C}$ ) and UVA and UVC postexposure and finishing 9 and 10 minutes, respectively. For the laser ablation, we have used laser imager for direct exposure on flexo plates (energy $4 \mathrm{~J} / \mathrm{cm}^{2}$, resolution $2450 \mathrm{ppi}$ ). The printing process was performed on roll fed flexo printing machine on matte duplex cardboard $270 \mathrm{~g} / \mathrm{m}^{2}$ using water-based colors and printing speed of $600 \mathrm{~m} / \mathrm{min}$. During the experiment, 17 cardboard rolls, or 82025 meters, were printed with the same printing plates. The sampling was done at the beginning of the print, after 11 and after 17 printed rolls. The measurements were done on the solid tone area of each prewashed printing plates. Amplitude surface roughness parameters, Ra, Rp, Rv and Rz, were measured at 11 positions, in printing and cross printing direction, whereas 32 measurements for each parameter was used for further statistical one factorial ANOVA analysis in SPSSv20 statistical tool. For the surface roughness measurements, we have used hand held portable stylus roughness tester TR 200: cut-off 0.80 $\mathrm{mm}$, sampling length 5xcut-off, Gauss filter, resolution $0.01 \mu \mathrm{m}$, measuring speed $\mathrm{Vt}=0.5 \mathrm{~mm} / \mathrm{s}$.

In results presentation, the values measured from the printing plates before printing, after 1 and 17 rolls, will be noted as 1, 2 and 3, respectfully.

Table 1: Technical parameters of used flexo printing plates

\begin{tabular}{|c|c|}
\hline Thickness & $1.70 \mathrm{~mm}$ \\
\hline Hardness & 69 Shore A \\
\hline Ton value reproduction & $1-95 \%$ \\
\hline Minimal line width & $80 \mu \mathrm{m}$ \\
\hline Minimal single dot diameter & $150 \mu \mathrm{m}$ \\
\hline
\end{tabular}

\section{RESULTS AND DISCUSSION}

Direct profilometric measurements of flexo printing plates resulted in a range of profilometric parameters' values, providing a basis for a further statistical analysis (Table 2, Table 3 and Table 4). The measured roughness profiles, for all three colors, indicate a remarkable similarity in corresponding surface roughness parameters values. 
Table 2: Surface roughness parameters of three flexo printing plates (cyan process color)

\begin{tabular}{|c|c|c|c|c|}
\hline & Plate & Average value $(\mu \mathrm{m})$ & Std. Dev. & Koef. of variation (\%) \\
\hline \multirow{3}{*}{ Ra } & 1 & 0.083 & 0.014 & 17.05 \\
\cline { 2 - 5 } & 2 & 0.082 & 0.048 & 12.24 \\
\cline { 2 - 5 } & 3 & 0.073 & 0.010 & 13.72 \\
\hline \multirow{3}{*}{$\operatorname{Rp}$} & 1 & 0.216 & 0.042 & 19.61 \\
\cline { 2 - 5 } & 2 & 0.223 & 0.048 & 21.54 \\
\hline \multirow{3}{*}{$\operatorname{Rv}$} & 3 & 0.210 & 0.034 & 16.24 \\
\cline { 2 - 5 } & 1 & 0.222 & 0.049 & 21.88 \\
\hline \multirow{3}{*}{$\operatorname{Rz}$} & 2 & 0.213 & 0.034 & 15.90 \\
\cline { 2 - 5 } & 3 & 0.183 & 0.036 & 19.48 \\
\cline { 2 - 5 } & 2 & 0.438 & 0.041465 & 23.33 \\
\hline
\end{tabular}

Table 3: Sufrace roughness parameters of three flexo printing plates (magenta process color)

\begin{tabular}{|c|c|c|c|c|}
\hline & Plate & Average value $(\mu \mathrm{m})$ & Std. Dev. & Koef. of variation (\%) \\
\hline \multirow{3}{*}{$\operatorname{Ra}$} & 1 & 0.079 & 0.012 & $15.56 \%$ \\
\cline { 2 - 5 } & 2 & 0.077 & 0.007 & $9.61 \%$ \\
\cline { 2 - 5 } & 3 & 0.071 & 0.015 & $21.49 \%$ \\
\hline \multirow{3}{*}{$\operatorname{Rp}$} & 1 & 0.291 & 0.071 & $24.37 \%$ \\
\cline { 2 - 5 } & 2 & 0.246 & 0.052 & $21.01 \%$ \\
\cline { 2 - 5 } & 3 & 0.213 & 0.045 & $21.34 \%$ \\
\hline \multirow{3}{*}{$\operatorname{Rv}$} & 1 & 0.206 & 0.041 & $20.02 \%$ \\
\cline { 2 - 5 } & 2 & 0.204 & 0.034 & $16.78 \%$ \\
\hline \multirow{3}{*}{$\operatorname{Rz}$} & 3 & 0.177 & 0.043 & $24.04 \%$ \\
\cline { 2 - 5 } & 1 & 0.496 & 0.101 & $20.37 \%$ \\
\cline { 2 - 5 } & 2 & 0.450 & 0.073 & $16.17 \%$ \\
\hline
\end{tabular}

Table 4: Sufrace roughness parameters of three flexo printing plates (blue spot color)

\begin{tabular}{|c|c|c|c|c|}
\hline & Plate & Average value $(\mu \mathrm{m})$ & Std. Dev. & Koef. of variation (\%) \\
\hline \multirow{3}{*}{ Ra } & 1 & 0.080 & 0.008 & 9.81 \\
\cline { 2 - 5 } & 2 & 0.076 & 0.010 & 13.55 \\
\cline { 2 - 5 } & 3 & 0.072 & 0.013 & 18.11 \\
\hline \multirow{3}{*}{ Rp } & 1 & 0.185 & 0.039 & 21.03 \\
\cline { 2 - 5 } & 2 & 0.202 & 0.030 & 14.74 \\
\cline { 2 - 5 } & 3 & 0.240 & 0.046 & 19.00 \\
\hline \multirow{3}{*}{ Rv } & 1 & 0.217 & 0.034 & 15.56 \\
\cline { 2 - 5 } & 2 & 0.202 & 0.021 & 10.32 \\
\hline \multirow{3}{*}{ Rz } & 3 & 0.181 & 0.035 & 19.45 \\
\cline { 2 - 5 } & 1 & 0.402 & 0.065 & 16.10 \\
\cline { 2 - 5 } & 2 & 0.405 & 0.072 & 17.85 \\
\hline
\end{tabular}

According to values represented in Tables 2-4, we have detected decreeing tendency in average surface roughness parameter in dependence of print run. Namely, overall surface roughness expressed through the value of Ra parameter is decreased after printing 11 rolls of cardboard. It is clearly showing that the flexo plate surface is becoming smoother. This is also reflected through the values of $R p, R v$ and $R z$ parameter for two process colors indicating that the longer interaction of printing plate, ink and printing substrate, followed with the applied printing pressure and printing speed, results in wearing the profile peaks and lowering valleys depth. The exception from this are $\mathrm{Rp}$ and $\mathrm{Rz}$ values for the printing plate for blue spot color, where, on contrary, we detect the mild increasing tendency with the print run. The changes detected in highest peak value may be due to possible higher granulation of printing ink, or their abrasive nature, where there is possibility that micro damages might occur on the flexo printing plate 
surface which might be detected as profile peaks. The value of coefficient of variation is below $25 \%$ which classifies the obtained measurement as stable and repeatable, with low variability (Papić, 2020).

\subsection{Statistical analysis}

In order to determine level of significance of changes in surface roughness parameters due to print run, statistical analysis method, independent-samples t-tests were performed. In Tables 5 - 13 are presented statistical test results carried out for a 5\% significance level, i.e., for a 95\% confidence level.

Table 5: Independent-samples t-test carried out for surface roughness parameters obtained on plate 1 and 2 (cyan process color)

\begin{tabular}{|c|c|c|c|c|c|c|c|}
\hline \multicolumn{8}{|c|}{ Independent Samples Test } \\
\hline & \multirow{3}{*}{$\begin{array}{l}\text { Partial Eta } \\
\text { squared }\left(\eta^{2}\right)\end{array}$} & \multirow[b]{3}{*}{ Sig. } & \multicolumn{5}{|c|}{ t-test for Equality of Means } \\
\hline & & & \multirow[b]{2}{*}{$\mathrm{t}$} & \multirow[b]{2}{*}{$\mathrm{df}$} & \multirow{2}{*}{$\begin{array}{c}\text { Sig. } \\
\text { (2-tailed) }\end{array}$} & \multicolumn{2}{|c|}{$\begin{array}{l}95 \% \text { Confidence } \\
\text { Interval of the } \\
\text { Difference }\end{array}$} \\
\hline & & & & & & Lower & Upper \\
\hline $\mathrm{Ra}$ & 0.002 & .062 & .327 & 62 & .745 & -.005107 & .007107 \\
\hline $\mathrm{Rp}$ & 0.002 & .003 & -.382 & 62 & .704 & -.040124 & .027249 \\
\hline $\mathrm{Rv}$ & 0.012 & .551 & .868 & 62 & .389 & -.011840 & .030027 \\
\hline $\mathrm{Rz}$ & 0.000 & .017 & .120 & 62 & .905 & -.041468 & .046781 \\
\hline
\end{tabular}

Table 6: Independent-samples t-test carried out for surface roughness parameters obtained on plate 2 and 3 (cyan process color)

\begin{tabular}{|c|c|c|c|c|c|c|c|}
\hline \multicolumn{8}{|c|}{ Independent Samples Test } \\
\hline & \multirow{3}{*}{$\begin{array}{l}\text { Partial Eta } \\
\text { squared }\left(\eta^{2}\right)\end{array}$} & \multirow[b]{3}{*}{ Sig. } & \multicolumn{5}{|c|}{ t-test for Equality of Means } \\
\hline & & & \multirow[b]{2}{*}{$\mathrm{t}$} & \multirow[b]{2}{*}{$d f$} & \multirow{2}{*}{$\begin{array}{c}\text { Sig. } \\
\text { (2-tailed) }\end{array}$} & \multicolumn{2}{|c|}{$\begin{array}{l}\text { 95\% Confidence } \\
\text { Interval of the } \\
\text { Difference }\end{array}$} \\
\hline & & & & & & Lower & Upper \\
\hline $\mathrm{Ra}$ & 0.163 & .779 & 3.473 & 62 & .001 & .003686 & .013689 \\
\hline $\mathrm{Rp}$ & 0.008 & .015 & .688 & 62 & .494 & -.024465 & .050152 \\
\hline $\mathrm{Rv}$ & 0.098 & .022 & 2.596 & 62 & .012 & .006876 & .052936 \\
\hline $\mathrm{Rz}$ & 0.047 & .022 & 1.758 & 62 & .084 & -.005860 & .091360 \\
\hline
\end{tabular}

Table 7: Independent-samples t-test carried out for surface roughness parameters obtained on plate 1 and 3 (cyan process color)

\begin{tabular}{|c|c|c|c|c|c|c|c|}
\hline \multicolumn{8}{|c|}{ Independent Samples Test } \\
\hline & \multirow{3}{*}{$\begin{array}{c}\text { Partial Eta } \\
\text { squared }\left(\eta^{2}\right)\end{array}$} & \multirow[b]{3}{*}{ Sig. } & \multicolumn{5}{|c|}{ t-test for Equality of Means } \\
\hline & & & \multirow[b]{2}{*}{$t$} & \multirow[b]{2}{*}{$d f$} & \multirow{2}{*}{$\begin{array}{c}\text { Sig. } \\
\text { (2-tailed) }\end{array}$} & \multicolumn{2}{|c|}{$\begin{array}{l}95 \% \text { Confidence } \\
\text { Interval of the } \\
\text { Difference }\end{array}$} \\
\hline & & & & & & Lower & Upper \\
\hline $\mathrm{Ra}$ & 0.139 & .045 & 3.168 & 62 & .002 & .003575 & .015800 \\
\hline $\mathrm{Rp}$ & 0.001 & .949 & .290 & 62 & .773 & -.037781 & .050593 \\
\hline $\mathrm{Rv}$ & 0.126 & .187 & 2.985 & 62 & .004 & .012881 & .065119 \\
\hline $\mathrm{Rz}$ & 0.042 & .762 & 1.650 & 62 & .104 & -.009620 & .100432 \\
\hline
\end{tabular}


In Tables 5-7 are presented results of independent-samples t-test carried out for surface roughness parameters obtained on plates for cyan process color. The result presented in column Sig. (significance) and partial eta squared indicates the presence of the statistical significance and the degree of influence on the result. Statistical significance at level of $<0.05$ for the average surface roughness was denoted between 1 and 3 printing plate indicating that the changes in surface roughness influenced by print run are significant. The values of partial eta squared points out the high effect size and confirms determined statistical significance between mean values of roughness parameter Ra measured on printing plates used for different print runs (according to Cohen, if partial eta squared is higher than 0.14 than it can be denoted high effect size (Pallant, 2007). If we look at the expressed statistical significance for the other three parameters which reflects the changes in more specific surface attributes, peaks and valleys, we can see that the statistically significant result was obtained between 1 and 2 , and 2 and 3 printing plate.

Table 8: Independent-samples t-test carried out for surface roughness parameters obtained on plate 1 and 2 (magenta process color)

\begin{tabular}{|c|c|c|c|c|c|c|c|}
\hline \multicolumn{8}{|c|}{ Independent Samples Test } \\
\hline & \multirow{3}{*}{$\begin{array}{l}\text { Partial Eta } \\
\text { squared }\left(n^{2}\right)\end{array}$} & \multirow[b]{3}{*}{ Sig. } & \multicolumn{5}{|c|}{ t-test for Equality of Means } \\
\hline & & & \multirow[b]{2}{*}{$\mathrm{t}$} & \multirow[b]{2}{*}{$d f$} & \multirow{2}{*}{$\begin{array}{c}\text { Sig. } \\
\text { (2-tailed) }\end{array}$} & \multicolumn{2}{|c|}{$\begin{array}{l}95 \% \text { Confidence } \\
\text { Interval of the } \\
\text { Difference }\end{array}$} \\
\hline & & & & & & Lower & Upper \\
\hline $\mathrm{Ra}$ & 0.003 & .000 & .411 & 62 & .683 & -.008216 & .012466 \\
\hline $\mathrm{Rp}$ & 0.032 & .000 & 1.440 & 62 & .155 & -.017427 & .107239 \\
\hline Rv & 0.000 & .000 & .107 & 62 & .915 & -.026418 & .029418 \\
\hline $\mathrm{Rz}$ & 0.024 & .000 & 1.227 & 62 & .224 & -.029172 & .121984 \\
\hline
\end{tabular}

Table 9: Independent-samples t-test carried out for surface roughness parameters obtained on plate 2 and 3 (magenta process color)

\begin{tabular}{|c|c|c|c|c|c|c|c|}
\hline \multicolumn{8}{|c|}{ Independent Samples Test } \\
\hline & \multirow{3}{*}{$\begin{array}{l}\text { Partial Eta } \\
\text { squared }\left(\eta^{2}\right)\end{array}$} & \multirow[b]{3}{*}{ Sig. } & \multicolumn{5}{|c|}{ t-test for Equality of Means } \\
\hline & & & \multirow[b]{2}{*}{$\mathrm{t}$} & \multirow[b]{2}{*}{$\mathrm{df}$} & \multirow{2}{*}{$\begin{array}{c}\text { Sig. } \\
\text { (2-tailed) }\end{array}$} & \multicolumn{2}{|c|}{$\begin{array}{l}95 \% \text { Confidence } \\
\text { Interval of the } \\
\text { Difference }\end{array}$} \\
\hline & & & & & & Lower & Upper \\
\hline $\mathrm{Ra}$ & 0.053 & .000 & 1.868 & 62 & .066 & -.000393 & .011643 \\
\hline $\mathrm{Rp}$ & 0.055 & .003 & 1.891 & 62 & .063 & -.001912 & .068599 \\
\hline Rv & 0.113 & .426 & 2.808 & 62 & .007 & .007813 & .046437 \\
\hline Rz & 0.120 & .195 & 2.906 & 62 & .005 & .018835 & .101852 \\
\hline
\end{tabular}

Table 10: Independent-samples t-test carried out for surface roughness parameters obtained on plate 1 and 3 (magenta process color)

\begin{tabular}{|c|c|c|c|c|c|c|c|}
\hline \multicolumn{8}{|c|}{ Independent Samples Test } \\
\hline & \multirow{3}{*}{$\begin{array}{c}\text { Partial Eta } \\
\text { squared }\left(\eta^{2}\right)\end{array}$} & \multirow[b]{3}{*}{ Sig. } & \multicolumn{5}{|c|}{ t-test for Equality of Means } \\
\hline & & & \multirow[b]{2}{*}{$\mathrm{t}$} & \multirow[b]{2}{*}{ df } & \multirow{2}{*}{$\begin{array}{c}\text { Sig. } \\
\text { (2-tailed) }\end{array}$} & \multicolumn{2}{|c|}{$\begin{array}{l}\text { 95\% Confidence } \\
\text { Interval of the } \\
\text { Difference }\end{array}$} \\
\hline & & & & & & Lower & Upper \\
\hline $\mathrm{Ra}$ & 0.029 & .000 & 1.362 & 62 & .178 & -.003628 & .019128 \\
\hline $\mathrm{Rp}$ & 0.081 & .001 & 2.342 & 62 & .022 & .011454 & .145046 \\
\hline $\mathrm{Rv}$ & 0.058 & .001 & 1.952 & 62 & .055 & -.000685 & .057935 \\
\hline $\mathrm{Rz}$ & 0.107 & .001 & 2.730 & 62 & .008 & .028571 & .184929 \\
\hline
\end{tabular}


In Tables 8-10 are presented results of independent-samples t-test carried out for surface roughness parameters obtained on plates for magenta process color.

Statistical significance at level of $<0.05$ for the average surface roughness was denoted between all printing plates indicating that the changes in surface roughness influenced by print run are significant. The values of partial eta squared points out the small to mild effect size (Pallant, 2007). If we look at the statistical significance values for the other three parameters it is noticed that the statistically significant result was not only obtained between 2 and 3 printing plate and Rv and Rz surface roughness parameters.

Table 11: Independent-samples t-test carried out for surface roughness parameters obtained on plate 1 and 2 (blue spot color)

\begin{tabular}{|c|c|c|c|c|c|c|c|}
\hline \multicolumn{8}{|c|}{ Independent Samples Test } \\
\hline & \multirow{3}{*}{$\begin{array}{c}\text { Partial Eta } \\
\text { squared }\left(\eta^{2}\right)\end{array}$} & \multirow[b]{3}{*}{ Sig. } & \multicolumn{5}{|c|}{ t-test for Equality of Means } \\
\hline & & & \multirow[b]{2}{*}{$\mathrm{t}$} & \multirow[b]{2}{*}{$\mathrm{df}$} & \multirow{2}{*}{$\begin{array}{c}\text { Sig. } \\
\text { (2-tailed) }\end{array}$} & \multicolumn{2}{|c|}{$\begin{array}{l}\text { 95\% Confidence } \\
\text { Interval of the } \\
\text { Difference }\end{array}$} \\
\hline & & & & & & Lower & Upper \\
\hline $\mathrm{Ra}$ & 0.049 & .084 & 1.786 & 62 & .079 & -.000483 & .008608 \\
\hline $\mathrm{Rp}$ & 0.039 & .284 & -1.583 & 62 & .118 & -.040019 & .004644 \\
\hline $\mathrm{Rv}$ & 0.040 & .352 & 1.614 & 62 & .112 & -.003615 & .033928 \\
\hline $\mathrm{Rz}$ & 0.000 & .554 & -.148 & 62 & .883 & -.036794 & .031731 \\
\hline
\end{tabular}

Table 12: Independent-samples t-test carried out for surface roughness parameters obtained on plate 2 and 3 (blue spot color)

\begin{tabular}{|c|c|c|c|c|c|c|c|}
\hline \multicolumn{8}{|c|}{ Independent Samples Test } \\
\hline & \multirow{3}{*}{$\begin{array}{c}\text { Partial Eta } \\
\text { squared }\left(n^{2}\right)\end{array}$} & \multirow[b]{3}{*}{ Sig. } & \multicolumn{5}{|c|}{ t-test for Equality of Means } \\
\hline & & & \multirow[b]{2}{*}{$t$} & \multirow[b]{2}{*}{$\mathrm{df}$} & \multirow{2}{*}{$\begin{array}{c}\text { Sig. } \\
\text { (2-tailed) }\end{array}$} & \multicolumn{2}{|c|}{$\begin{array}{l}\text { 95\% Confidence } \\
\text { Interval of the } \\
\text { Difference }\end{array}$} \\
\hline & & & & & & Lower & Upper \\
\hline $\mathrm{Ra}$ & 0.025 & .084 & 1.272 & 62 & .208 & -.002126 & .009563 \\
\hline $\mathrm{Rp}$ & 0.137 & .819 & -3.131 & 62 & .003 & -.061240 & -.013510 \\
\hline Rv & 0.046 & .135 & 1.730 & 62 & .089 & -.003266 & .045328 \\
\hline Rz & 0.012 & .466 & -.866 & 62 & .390 & -.054080 & .021392 \\
\hline
\end{tabular}

Table 13: Independent-samples t-test carried out for surface roughness parameters obtained on plate 1 and 3 (blue spot color)

\begin{tabular}{|c|c|c|c|c|c|c|c|}
\hline \multicolumn{8}{|c|}{ Independent Samples Test } \\
\hline & \multirow{3}{*}{$\begin{array}{c}\text { Partial Eta } \\
\text { squared }\left(\eta^{2}\right)\end{array}$} & \multirow[b]{3}{*}{ Sig. } & \multicolumn{5}{|c|}{ t-test for Equality of Means } \\
\hline & & & \multirow[b]{2}{*}{$t$} & \multirow[b]{2}{*}{$\mathrm{df}$} & \multirow{2}{*}{$\begin{array}{c}\text { Sig. } \\
\text { (2-tailed) }\end{array}$} & \multicolumn{2}{|c|}{$\begin{array}{l}95 \% \text { Confidence } \\
\text { Interval of the } \\
\text { Difference }\end{array}$} \\
\hline & & & & & & Lower & Upper \\
\hline $\mathrm{Ra}$ & 0.120 & .001 & 2.903 & 62 & .005 & .002424 & .013139 \\
\hline $\mathrm{Rp}$ & 0.304 & .125 & -5.201 & 62 & .000 & -.076224 & -.033901 \\
\hline Rv & 0.139 & .021 & 3.162 & 62 & .002 & .013312 & .059063 \\
\hline $\mathrm{Rz}$ & 0.017 & .178 & -1.048 & 62 & .299 & -.054868 & .017118 \\
\hline
\end{tabular}


In Tables 11-13 are presented results of independent-samples t-test carried out for surface roughness parameters obtained on plates for blue spot color. The result presented in column Sig. (significance) and partial eta squared indicates the presence of the statistical significance and the degree of influence on the result. Statistical significance, looking at the average surface roughness, was denoted between 1 and 3 printing plate indicating that the changes in surface roughness influenced by print run are significant. The value of partial eta squared value confirms high effect size (Pallant, 2007). If we look at the expressed statistical significance for the peaks and valleys, we can see that the statistically significant result was obtained only between 1 and 3 printing plate and only for the Rv surface roughness parameter. This may lead to the conclusion that during printing, statistically there are no significant changes in the average values of the highest peaks and lowest valleys.

\section{CONCLUSIONS}

In this paper detailed statistical surface roughness analysis of CtP flexo plates in correlation with print run was conducted. The conclusions derived from the conducted research are as follows:

- $\quad$ The changes in values of four amplitude surface roughness parameters ( $R a, R p, R v$ and $R z)$ due to print run, obtained by the by direct stylus profilometric method, generally correspond to anticipated trend: longer print run will result in lowering the surface roughness of the flexo printing plate.

- The decreasing tendency is clearly expressed through changes of the average surface roughness value - Ra: the differences between average Ra values at the beginning of the printing and after 82025 meters of printed material were found to be statistically different in case of all printing plates utilized in the experiment.

- $\quad$ On the basis of values obtained for more specific surface roughness parameters - peaks and valleys $(R p, R v$ and $R z$ ), it is seen that the longer print run will, generally lead to in wearing the profile peaks and lowering valleys depth. The contradictory result was obtained only in case of Rp and Rz values for the printing plate for blue spot color. The noticed increasing tendency, may indicate that the abrasive nature of printing inks or substrate may lead to micro damages on the flexo printing plate surface which might be detected as profile peaks.

- Values of partial eta squared points out the mild to high influence of print run on the changes in surface roughness of digital flexo printing plates.

- The statistical analysis reveal that the influence of print run on changes of the peak and valleys surface roughness values may not be in case of all printing plates considered as statistically significant. This might be connected with the type of ink used (process vs. spot colors) and its characteristics in terms of granulation and influence on the printing plate surface.

- With further analysis, extended on other printing substrates and inks, as well as printing plates in terms of processing parameters, this research can be significantly upgraded and may deeply reveal the changes in surface roughness on the CtP flexo printing plates in dependace of print run.

\section{ACKNOWLEDGMENTS}

This research (paper) has been supported by the Ministry of Education, Science and Technological Development through the project no. 451-03-68/2020-14/200156: "Innovative scientific and artistic research from the FTS (activity) domain".

\section{REFERENCES}

[1] Barros, G.G., Fahlcrantz, C.M., Johansson, P.A.: "Topographic distribution of uncovered areas (UCA) in full tone flexographic prints", Taga Journal 2 (1), 43-57, 2005.

[2] Bould, D. C., Claypole, T. C.,Bohan, M. F. J., Gethin, D. T.: "Deformation of Flexographic Printing Plates", URL: http://www.printing.org/page/8623\#, (last request: 2018-05-18).

[3] Chappard, D., Degasne, I., Huré, G., Legrand, E., Audran, M., Baslé, Mf.: "On image analysis measurements of roughness by texture and fractal analysis correlate with contact profilometry", Biomaterials 24 (8), 1399-1407, 2003. doi: 10.1016/s0142-9612(02)00524-0.

[4] Choi, J., O'Brate, K.: US 2010/0173135 A1, "Method of Controlling Surface Roughness of a Flexographic Printing Plate", United States Patent, 2010. 
[5] Dedijer, S., Novaković, D. Pál, M. Pavlović, Ž.: "Statistical analysis of printing elements reproduction on thermally developed CTP flexo printing plates", Journal Of Graphic Engineering And Design 3, 12 22, 2012

[6] Kipphan H.: "Handbook of Print Media", (Springer, Berlin,2001.), pages 503-626.

[7] Lanska D. J.: "Common-Sence Flexography - A User's Guide to Improved Pressroom Productivity", (Printing Industries Press, Pittsburg, 2007.).

[8] Mahović, S.: "Karakterizacija površinskih struktura ofsetnih tiskovnih formi - doktorska disertacija", (Sveučilište U Zagrebu, Grafički Fakultet, 2007.), pages 38-50.

[9] Pallant, J: "Postupni vodič kroz analizu podataka pomoću SPSS-a za Windows (verzija 15)", (Allen\&Unvin, Mikro knjiga, Beograd, 2007.).

[10] Papić, M.: "Poslovna statistika", URL: http://www.oss.unist.hr/zg/rif/kolegiji/20100301_pred_PSTA.pdf, (last request: 2020-09-12).

[11] Pavlović, Ž., Novaković, D., Dedijer, S., Apro, M.: "Changes in the surface roughness of aluminium oxide (non-printing) areas on offset printing plate depending on number of imprints", Journal Of Graphic Engineering And Design 1 (1), 32 -38, 2010.

[12] Rentzhog, M.: "Water-Based Flexographic Printing on Polymer-Coated Board", Doctoral Thesis, Royal Institute of Technology Stockholm, Sweden, 2006.

[13] Risović, D., Mahović - Poljaček, S., Gojo, M.: "On correlation between fractal dimension and profilometric parameters in characterization of surface topographies", Applied Surface Science 255(7), 4283-4288, 2009. doi: 10.1016/j.apsusc.2008.11.028.

(C) 2020 Authors. Published by the University of Novi Sad, Faculty of Technical Sciences, Department of Graphic Engineering and Design. This article is an open access article distributed under the terms and conditions of the Creative Commons Attribution license 3.0 Serbia (http://creativecommons.org/licenses/by/3.0/rs/). 